\title{
Impact of EFL Teachers' Collective Efficacy and Job Stress on Job Satisfaction
}

\author{
Suleyman Davut Göker \\ Department of English Translation and Interpretation, Faculty of Humanities, Girne American University, North \\ Cyprus via Mersin 10, 98000 Turkey \\ Email: gokersd@yahoo.com
}

\begin{abstract}
This study examines the impact of EFL (English as a foreign language) teachers' collective efficacy (TCE) and job stress on job satisfaction. The participants were 25 EFL instructors from English Foundation School, Girne American University, North Cyprus who responded to the TCE, Job Stess and Job Satisfaction Questionnaires. Findings supported the hypotheses that TCE predicted job satisfaction in EFL setting in North Cyprus and job stress was negatively related to job satisfaction for EFL instructors. The results from this study provide evidence that TCE and job stress in an EFL context influence job satisfaction. At a broader level, the study is the first to examine teachers' collective motivation beliefs in an EFL setting. For educators, this study underlines the importance of TCE as a source of individual job satisfaction.
\end{abstract}

Index Terms - teachers, collective efficacy, EFL setting, job satisfaction, job stress

\section{INTRODUCTION}

Concept of self-efficacy perceptions was introduced by Albert Bandura (1977) with a meaning of "beliefs in one's capacity to organize and execute the courses of action required to produce given attainments" (Bandura, 1997, p. 3). Since then, research studies conducted in many fields have shown the power of efficacy judgments in human learning, performance, and motivation. For instance, these efficacy beliefs have been found to be related to smoking cessation, adherence to exercise and diet programs, performance in sports, political participation, and academic achievement (Bandura, 1997).

The last field is of particular importance to educators. During the last two decades, links between student achievement and three kinds of efficacy beliefs - the self-efficacy judgments of students (Pajares, 1994, 1997), teachers' beliefs in their own instructional efficacy (Goker, 2006b; Tschannen-Moran, Woolfolk Hoy, \& Hoy, 1998), and teachers' beliefs about the collective efficacy of their school (Goddard, Hoy, \& Woolfolk Hoy, 2000) were studied by the researchers in the field of education.

Perceived collective efficacy is the most recent construct developed and has received the least attention from educational researchers among these three efficacy beliefs. Despite the fact that the large number of studies on teacher efficacy have been done in different subject areas, no study addressing the role of collective-efficacy and job stress in job satisfaction has been done with the population of teachers in an EFL setting. This study examines how teachers' collective efficacy (TCE) beliefs and job stress are associated with job satisfaction for EFL instructors in North Cyprus.

Almost all discussions of the effectiveness of teaching and learning process have placed a great emphasis on teachers' actions and behaviors that are associated with their attitudes, perceptions, beliefs, assumptions, and motivation levels. When they gain satisfaction from their work, teachers naturally display higher levels of motivated behavior and performance as well as lower levels of stress, anxiety, and burnout (e.g., Brouwers \& Tomic, 2000; Caprara, Barbaranelli, Borgogni, \& Steca, 2003; Caprara, Barbaranelli, Steca, \& Malone, 2006; Green-glass \& Burke, 2003).

Teachers' Collective Efficacy

Findings of recent studies have demonstrated that teachers' self-efficacy is related to a host of positive factors in the classroom, including better student outcomes, reduced stress, and career longevity (Woolfolk-Hoy \& Davis, 2006). However, less attention has been given to TCE, which refers to the beliefs teachers possess in their collective capabilities to influence the lives of their students (Tschannen-Moran, Woolfolk Hoy, \& Hoy, 1998). When teachers are satisfied with their work, they may possess a strong sense of their own capabilities in their work. Effective schools are characterized by stakeholders who have a collective sense in their efficacy to help students develop and learn.

Bandura (1997) asserted that individuals do not work as social isolates, and therefore people form beliefs about the collective capabilities of the group(s) to which they belong. He defined perceived collective efficacy as "a group's shared belief in its conjoint capabilities to organize and execute the courses of action required to produce given levels of attainments" (p. 477). Such group referent perceptions show an emergent organizational property known as perceived collective efficacy (see, e.g., Bandura, 1997; Goddard, Hoy, \& Woolfolk Hoy, 2000; Hoy, Sweetland, \& Smith, 2002). Within a school, perceived collective efficacy, then, represents the judgement of teachers that the faculty as a whole can organize and execute the necessary courses of action in order to have a positive effect on student learning. 
According to findings of some studies, TCE is found to be related to student achievement and academic climate, even after controlling for previous student achievement and demographic characteristics such as socioeconomic status (e.g., Bandura, 1993; Klassen, Chong, Huan, Wong, Kates, \& Hannok, 2008). In most of these studies, links between TCE and professional commitment and teachers' sense of community have been found (Ciani, Summers, \& Easter, 2008; Ross \& Gray, 2006; Ware \& Kitsantas, 2007). Schools, where teachers have high collective efficacy beliefs may also be those in which administrators, students, and parents are generally more supportive (Goddard \& Goddard, 2001).

\section{Job Satisfaction and Job Stress}

According to Bandura (2000), groups with higher levels of collective efficacy are more likely to persist in trying to solve problems if they face with obstacles and efficacy beliefs affect what people prefer to do as a group, how much effort they put into it and their staying power when collective efforts fail to produce results. Thus, we can say that employees with lower efficacy may call in sick rather than face another day of frustration on a job they feel unable to perform, whereas employees with higher efficacy are likely to exhibit fewer withdrawal behaviours, because they may expend more effort and persistence in task performance (Bandura, 1986). All these opinions have received support empirically. For example, Hochwarter, Kiewitz, Castro, Perrewe, \& Ferris. (2003) argued that persons with low collective efficacy were less satisfied with their jobs when levels of 'go-along-to-get-along' politics increased. Jex and Bliese (1999) and Jex and Thomas (2003) found collective efficacy related to job-related stressors and strains, and collective efficacy significantly related to average levels of job satisfaction and organizational commitment.

Teachers who have higher levels of job satisfaction are likely to be better performers than dissatisfied teachers. Job satisfaction is considered to be the degree of an employee's affective orientation toward the work roles. Locke (1976) defined job satisfaction as a pleasurable or positive emotional state resulting from an appraisal of one's job or job experiences (Locke, 1976, p. 1300). Locke further argues that job satisfaction explains what makes people want to come to work and makes them happy about their job or not to quite their jobs. Dawis and Lofquist (1984) also defined job satisfaction as "a pleasurable effective condition resulting from one's appraisal of the way in which the experienced job situation meets one's needs, values, and expectations". Therefore, job satisfaction could be fundamentally the result of effective behavior management.

Recently researchers have begun to empirically explore the relation between teachers' motivation and job-related factors. Teaching is considered to be a stressful occupation, with many demands from administrators, colleagues, students, and parents, shifting policies, and a lack of recognition for accomplishments (Greenglass \& Burke, 2003). Teacher stress is inversely related to teacher self-efficacy (Betoret, 2006; Skaalvik \& Skaalvik, 2007; Yoon, 2002) and positively related to poor teacher-pupil rapport and low levels of teacher effectiveness (Abel \& Sewell, 1999; Kokkinos, 2007). Teacher stress is also not inevitable in difficult conditions; teachers in schools where there is good communication among staff and a strong sense of collegiality express lower levels of stress and higher levels of commitment and job satisfaction (Kyriacou, 2001).

In spite of reported high levels of stress (Chaplain, 2008; National Education Association, 2007), teachers often find high levels of personal satisfaction from their work. Job satisfaction is considered to be associated with job commitment, and with high levels of performance (Judge, Thoresen, Bono, \& Patton, 2001). Caprara, Barbaranelli, Borgogni, \& Steca (2003) named job satisfaction a "decisive element" (p. 823) that affects teachers' behavior and performance, and he argued that self-efficacy and collective efficacy both contribute to teachers' job satisfaction.

\section{CurRent Study}

The purpose of this study is to provide an exploratory investigation into how TCE and job stress influence job satisfaction in an EFL setting. Specifically, we sought to determine what, if any, relationship existed between EFL instructors' perceived collective efficacy, job stress and job satisfaction together with two main demographic variables, which included previous teaching experience and nationality of the instructor with the following questions:

1. Do EFL instructors' perceived levels of collective efficacy influence job satisfaction?

2. Do EFL instructors' perceived levels of job stress influence job satisfaction?

3. Are there differences in the relative utility/power of the predictors of job satisfaction across the personal variables?

The hypotheses developed for this study are based on theory and recent empirical work. Firstly, we hypothesized that TCE will be positively related to job satisfaction, which is consistent with the general agreement among scholars and researchers that beliefs about group capability influence the actions of organizational members (Bandura, 1997; Goddard, Hoy, \& Hoy, 2000; Klassen, Usher, \& Bong, 2010; Raudenbush, Rowan, \& Cheong, 1992; Sampson, Morenoff, \& Earls, 2000). Secondly, it was predicted that job stress will be inversely related to job satisfaction in EFL contexts as teacher stress reflects unpleasant negative emotions such as anger, anxiety, and frustration (Jepson \& Forrest, 2006).

\section{METHOD}

\section{Participants}

A total of 27 EFL instructors from English Foundation School, Girne American University, North Cyprus were included in the study. 25 of them responded to the TCE, Job Stess and Job Satisfaction Questionnaires. The nationality 
of participants in this study were identified as 70\% Turkish Cypriot, and 30\% Other. 60\% of them had 0-5 year experience and $40 \%$ had 6-10 year teaching experience.

\section{Procedures}

Before administering the questionnaires, permission was received from the director of English Foundation School, Girne American University, North Cyprus and TCE, Job Stess and Job Satisfaction Questionnaires were sent to the English Foundation School on January 20, 2012 with the request that it be forwarded to the secretary of the school within two weeks. Participants were volunteers and 25 of the instructors responded to the questionnaires.

\section{Data Collection}

Teacher collective efficacy was measured using The Collective Teacher Efficacy Belief Scale (CTEBS) created by Tschannen-Moran and Barr (2004). This was a 12- item scale, with six items representing each of two factors: TCE for instructional strategies (e.g., "How much can teachers in your school do to produce meaningful student learning?"), and TCE for student discipline (e.g., "To what extent can teachers in your school make expectations clear about student behavior?"). The CTEBS was constructed to reflect teachers' individual perceptions about their school's collective capabilities to influence student achievement, and it is based on teachers' analysis of the teaching staff's capabilities to effectively teach all students.

Instructors from the same school may have differing perceptions of their school's collective efficacy as the CTEBS assesses individual perceptions of TCE. The CTEBS measure is conceptually superior to previous measures because it assesses teachers' beliefs in their collective capabilities rather than the external factors that influence student achievement (Tschannen-Moran \& Barr, 2004). The alpha reliability coefficient was .97, which was significantly correlated with school-level achievement (Tschannen-Moran \& Barr, 2004).

Consistent with the approach used in recent studies of teacher stress (e.g., Boyle, Borg, Falzon, \& Baglioni, 1995; Chaplain, 2008; Manthei, Gilmore, Tuck, \& Adair, 1996), job stress was measured using a single item ("I find teaching to be very stressful"). Job satisfaction was measured using a 4-item scale with strong evidence of reliability ( $\alpha=.82)$ and validity in a study conducted by Caprara et al. (2003). The following items were included: (a) "I am satisfied with my job," (b) "I am happy with the way my colleagues and superiors treat me," (c) "I am satisfied with what I achieve at work," and (d) "I feel good at work."

Ratings in the current study were completed using a 9-point response scale, (1= 'Not at all', 9= 'A great deal') with items summed to represent scores for each variable.

\section{DATA ANALYSIS}

For the four variables (TCE for instructional strategies and student discipline, job satisfaction, and job stress), descriptive statistics - reliability coefficients, means, and standard deviations - were examined. A MANOVA was used to investigate the combined variables, and bivariate correlations among the variables were further examined. Then, multigroup confirmatory factor analysis was used to test for the equivalency of the factorial measurement (i.e., itemlevel loadings on factors) across groups. The last analysis was the use of structural equation modeling to conduct multigroup path analysis to investigate how the independent variables of TCE and job stress were related to the dependent variable of job satisfaction.

\section{Reliabilities, Means, and Bivariate Correlations}

Table 1 shows reliabilities, means, and standard deviations for the variables in the study. All measures displayed adequate reliability, ranging from a low of $\alpha=.83$ for TCE for student discipline to a high of $\alpha=.89$ for TCE for instructional strategies for EFL teachers. As demonstrated in Table 1, the reliability coefficient for the Job Satisfaction was found to be $\alpha=0.84$. Finally, the reliability coefficient for Job Stress was $\alpha=.85$.

Turkish Cypriot EFL instructors' mean score for job satisfaction was $28.95 \pm 3.9$. The mean scores for the TCE for instructional strategies were found to be $44.1 \pm 5.6$, and $43.75 \pm 5.7$ for TCE for student discipline. And finally, EFL instructors' mean score for job stress was $7.05 \pm 5.5$. Foreign EFL instructors' mean score for job satisfaction was 24.96 \pm 4.9. The mean scores for the TCE for instructional strategies were found to be $38.13 \pm 6.2$, and $37.26 \pm 3.7$ for TCE for student discipline. And finally, EFL instructors' mean score for job stress was $4.26 \pm 2.2$.

TABLE 1

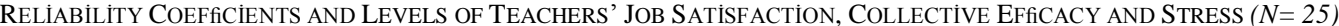

\begin{tabular}{|l|l|l|l|l|l|l|}
\multicolumn{1}{c|}{} & \multicolumn{2}{l|}{ Instructors from North Cyprus $(\boldsymbol{n}=\mathbf{1 7})$} & \multicolumn{2}{l|}{ Instructors from Other Countries $(\boldsymbol{n}=8)$} \\
\hline Variable & $\alpha$ & $\mathbf{M}$ & SD & $\alpha$ & M \\
\hline Job satisfaction & .84 & $28.95_{\mathrm{a}}$ & 3.94 & .86 & $24.96_{\mathrm{b}}$ & 4.95 \\
\hline $\begin{array}{l}\text { Teachers' collective efficacy for } \\
\text { instructional strategies }\end{array}$ & .89 & $44.17_{\mathrm{b}}$ & 5.65 & .85 & $38.13_{\mathrm{c}}$ & 6.22 \\
\hline $\begin{array}{l}\text { Teachers' collective efficacy for student } \\
\text { discipline }\end{array}$ & .83 & $43.75_{\mathrm{a}}$ & 5.71 & .87 & $37.26_{\mathrm{b}}$ & 3.75 \\
\hline Job stress & .85 & $7.05_{\mathrm{a}}$ & 5.58 & .83 & $4.26_{\mathrm{b}}$ & 2.28 \\
\hline
\end{tabular}

Note. Means that have the same subscript on the same line are not significantly different at $\mathrm{p}<.001$ using Scheff'e comparisons.

Findings of the MANOVA revealed that the combined dependent variables were significantly different among the groups, $F(7,868)=44.61, p<.001, \eta^{2}=.22$. Follow-up analyses of variance (ANOVAs) showed that means were 
similar on three of the four variables. Instructors from other countries rated all variables significantly lower than did instructors from North Cyprus (all $p \mathrm{~s}<.001$ ). However, instructors from other countries rated levels of job stress significantly lower than did instructors from North Cyprus, $F(2,568)=96.75, p<.001, \eta^{2}=.23$.

In Table 2, the bivariate correlations among the four variables are presented. The correlations among the variables demonsatrated similar directions and magnitudes for the instructors from North Cyprus and other countries.

TABLE 2

CORRElations FOR TEACHERS' JOB SATISFACTION, COLlECtive EFfiCACY, AND JOB STRESS (N=25)

\begin{tabular}{|c|c|c|c|c|c|c|}
\hline \multirow[b]{2}{*}{ Variable } & \multicolumn{3}{|c|}{ Instructors from North Cyprus $(n=17)$} & \multicolumn{3}{|c|}{ Instructors from Other Countries $(n=8)$} \\
\hline & 1 & 2 & 3 & 1 & 2 & 3 \\
\hline \multicolumn{7}{|l|}{ Job Satisfaction } \\
\hline $\begin{array}{l}\text { Teachers' collective efficacy for } \\
\text { instructional strategies }\end{array}$ & $35^{* * *}$ & & & $46^{* *}$ & & \\
\hline $\begin{array}{l}\text { Teachers' collective efficacy for } \\
\text { student discipline }\end{array}$ & $38^{* * *}$ & $.51 * *$ & & $48 * *$ & $.82 * *$ & \\
\hline Job stress & -.23 & $-.15 * *$ & $-.05 * *$ & .08 & $.30 * *$ & $.24 * *$ \\
\hline
\end{tabular}

The pattern of correlations showed similar directions for Turkish Cypriot instructors but some differences for instructors from other countries. Job stress was not significantly related to the two TCE variables for EFL instructors from North Cyprus, and it was significantly inversely related to job satisfaction. However, job stress was positively related to the two TCE subscales for EFL instructors from other countries and not significantly related to job satisfaction. In other words, for the EFL instructors from other nationalities, more confidence in the school's collective capability to influence student learning was related to higher levels of stress for individual teachers, but job stress was unrelated to job satisfaction.

For the subsequents anayses, factor loadings were examined and they were found to be significant for all items across groups, and they were moderate to high, ranging from .54 to .89 .

Figure 1 graphically portrays the path analysis. The four variables explained $23 \%$ of the job satisfaction variance for Turkish Cypriot instructors and $34 \%$ of the job satisfaction variance for EFL instructors from other nationalities.

Figure 1

Path Diagram for Variables Predicting Job Satisfaction for EFL Instructors

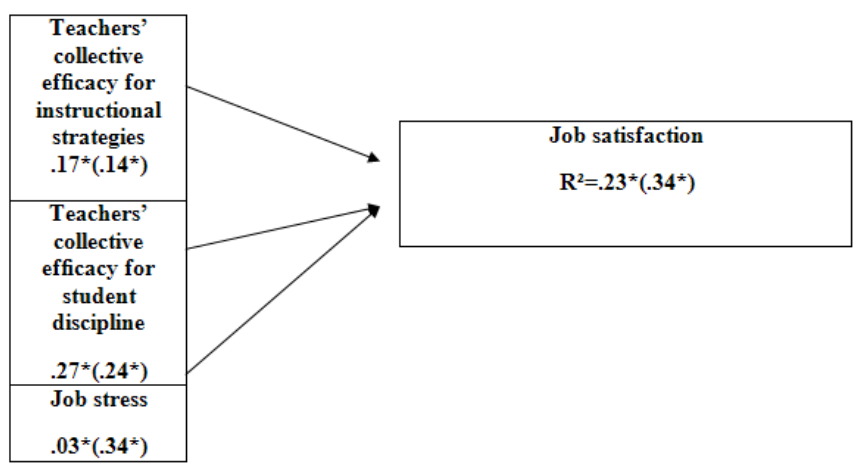

The results from the multigroup path analysis revealed group differences in the contribution of teacher collective efficacy and job stress to job satisfaction for EFL instructors from North Cyprus and other countries. Findings for EFL instructors from other countries are given in parantheses. Values represent standarized coefficients. $* p<.01$. $* * p$ $<.001$.

\section{DiSCUSSION AND CONCLUSION}

The aim of this study was to examine the relations among teachers' job satisfaction, collective efficacy, and job stress among EFL instructors from the English Foundation School, Girne American University, North Cyprus. The results from the study clarify the relation between TCE and some important correlates in an EFL setting and specifically point to differences in the roles played by job stress in their links with job satisfaction for EFL instructors at the Girne American University, North Cyprus. At a broader level, the study is the first to examine teachers' collective motivation beliefs in an EFL setting.

Findings supported the first hypothesis of this study that TCE would be positively related to job satisfaction in EFL setting and it was confirmed. As Bandura (1986) noted, collective efficacy requires group judgment and effort, along with persistence and a willingness for a group to remain together. Mayer, Mullens, and Moore (2000) are among those who emphasized the importance of "a school faculty that collectively takes responsibility for student learning" (p. 36). 
Empirical research also indicated that higher in group cohesion was associated with successful performance. For instance, Gardner, Shields, Bredemeier, \& Bostrom (1996) showed that group cohesion is hypothesized to positively influence performance and success. Carron, Bry, \& Eys (2002) demonstrated a strong positive relationship between cohesion and team success.

In a study of the relationship between coaching behavior and team cohesion, Gardner et al. (1996) found that higher levels of team cohesion accompanied perceptions of a coach's behavior that could be characterized by democratic behaviors including training and instruction, social support, and positive feedback. Attaching importance to peer coaching, Goker (2006b) also examined the impact of self-efficacy and instructional skills of EFL preservice teachers in Northern Cyprus, and found that peer coaching improved the self-efficacy of the teachers. It was also emphasized in the study that experiential activities, such as the teaching practicum or other mastery experiences potentially had a great impact on the self-efficacy of these preservice teachers.

Results gained in the present study also correlate with those of the studies (Ciani, Summers, \& Easter, 2008; Goddard \& Goddard, 2001; Ross \& Gray, 2006; Ware \& Kitsantas, 2007), which argue that schools in which teachers have high collective efficacy beliefs may also be those in which administrators, students, and parents are generally more supportive. Enhancing collective teacher efficacy by creating opportunities for teachers to build instructional knowledge and collaborate with colleagues through which, teachers will be seen as sources of expertise. By doing so, EFL school leaders will be able to transform their schools into organizations with strong collective efficacy and improved student performance. Therefore, teachers with high collective efficacy beliefs would also be great asset to EFL schools, which aim to have school-based reflective management (Goker, 2005, 2006a), where principals establish a focus on learning and students by consistently communicating that student learning is the shared mission of students, teachers, principals, and the community.

Thus, we can say that when teachers are happy with their jobs, they are likely to be better performers. In this sense, job satisfaction shows the degree of a teacher's affective orientation toward the work roles. Results of this study are also consistent with previous research that has shown TCE to explain modest but important variance in outcome variables such as student achievement and teachers' job satisfaction (Klassen et al., 2008; Tschannen-Moran \& Barr, 2004).

However, the second hypothesis of this study that job stress would be significantly associated with job satisfaction in an EFL setting was not confirmed, in other words, job stress was inversely correlated with job satisfaction for EFL teachers from North Cyprus. Approached from this angle, for EFL instructors from other countries, more confidence in the school's collective capability to affect student learning was associated with higher levels of stress for individual teachers, but job stress was unrelated to job satisfaction. However, for instructors from other countries, job stress was positively correlated with TCE, which means that they find themselves amidst colleagues whom they perceive as highly competent, they experience higher levels of job stress. They may also experience higher levels of job stress due to the fact that school management fails to nurture work culture. In this connection, the collectivist cultural tendency of upward social comparison and focus on better student outcomes may result in other teachers experiencing greater stress when working in schools where colleagues are perceived as high performing (Klassen et al., 2010). To avoid high levels of job stress, EFL school principals should nurture work cultures that value and support their members' learning by modeling, guiding, and facilitating participation in professional communities that value learning, building trusting relationships among professionals in the school or district, and promoting a focus on learning and associated core values (Goker, 2006a).

Even though this finding is not consistent with more research studies except for (Klassen et al., 2010), the fact that teaching is a stressful occupation and teacher stress is inversely related to teacher self-efficacy has received support empirically (Greenglass \& Burke, 2003; Betoret, 2006; Skaalvik \& Skaalvik, 2007; J. S. Yoon, 2002).

\section{LIMITATIONS}

In this study, a few key limitations to the work must be noted. First, this study involved self-report data and participation was voluntary; therefore, the study is limited by the data collected from participants who were interested and willing to participate in the study. Secondly, another key limitation of this study is that the sample of instructors was drawn from one university in North Cyprus and may not be nationally representative. Finally, the job stress measure consisted of only a single item. However, recent studies have included single item measures of job-related beliefs (e.g., Dolbier, Webster, McCalister, Mallon, \& Steinhardt, 2005; Nagy, 2002) due to high levels of face validity and convenience for data collection in busy workplace settings, and many previous studies measure job stress using one item (e.g., Chaplain, 2008; Manthei et al., 1996).

\section{IMPLICACATIONS}

At a broader level, the study is the first to examine teachers' collective motivation beliefs in an EFL setting. The results from this study provide evidence that TCE and job stress in an EFL context influences job satisfaction. For EFL scholar and educators, this study underlines the importance of TCE as a source of individual job satisfaction.Placing a great emphasis on the fact that TCE is an important factor that influences job satisfaction, results of this study highlight 
the importance of building collective efficacy by providing administrative support, couraging learner-centred teaching. Thus, developing collective efficacy may enhance job satisfaction in schools where stress may be reduced.

However, future research studies should extend these findings using longitudinal and qualitative approaches in order to better understand the relationship between collective and individual motivation beliefs in other EFL settings.

\section{REFERENCES}

[1] Abel, M. H., \& Sewell, J. (1999). Stress and burnout in rural and urban secondary school teachers. The Journal of Educational Research, 92, 287-293.

[2] Bandura, A. (1977). Selfefficacy: Toward a unifying theory of behavioral change. Psychological Review, 84, 191-215.

[3] Bandura, A. (1986). Social foundations of thought and action: A social cognitive theory. Englewood Cliffs, NJ: PrenticeHall.

[4] Bandura, A. (1993). Perceived self-efficacy in cognitive development and functioning. Educational Psychologist, 28(2), 117148 .

[5] Bandura, A. (1997). Selfefficacy: The exercise of control. New York: W. H. Freeman and Company.

[6] Bandura, A. (2000). Exercise of human agency through collective efficacy. Current Directions in Psychological Science, 9, 7578.

[7] Betoret, F. D. (2006). Stressors, self-efficacy, coping resources, and burnout among secondary school teachers in Spain. Educational Psychology, 26, 519-539.

[8] Boyle, G. J., Borg, M. G., Falzon, J. M., \& Baglioni Jr., A. J. (1995). A structural model of the dimensions of teacher stress. British Journal of Educational Psychology, 65, 49-67.

[9] Brouwers, A., \& Tomic,W. (2000). A longitudinal study of teacher burnout and perceived self-efficacy in classroom management. Teaching and Teacher Education, 16, 239-253.

[10] Caprara, G. V., Barbaranelli, C., Borgogni, L., \& Steca, P. (2003). Efficacy beliefs as determinants of teachers' job satisfaction. Journal of Educational Psychology, 95, 821-832.

[11] Caprara, G. V., Barbaranelli, C., Steca, P., \& Malone, P. S. (2006). Teachers' self-efficacy beliefs as determinants of job satisfaction and students' academic achievement: A study at the school level. Journal of School Psychology, 44, 473-490.

[12] Carron, A. V., Bry, S. R., \& Eys, M. A. (2002).Team cohesion \& team success in sport, Journal of Sport Science, v. 20, n. 2, p. 119-26.

[13] Chaplain, R. P. (2008). Stress and psychological distress among trainee secondary teachers in England. Educational Psychology, 28, 195-209.

[14] Ciani, K. D., Summers, J. J., \& Easter, M. A. A. (2008). Top-down analysis of high school teacher motivation. Contemporary Educational Psychology, 33, 533-560.

[15] Dawis, R. V. \& Lofquist, L. H. (1984). A Psychological Theory of Work Adjustment: An Individual-Differences Model and its Applicants. Minneapolis: University of Minnesota Press.

[16] Dolbier, C. L.,Webster, J. A., McCalister, K. T., Mallon, M.W.,\&Steinhardt, M. A. (2005). Reliability and validity of a singleitem measure of job satisfaction. American Journal of Health Promotion, 19, 194-198.

[17] Gardner, D. E., Shields, D. L., Bredemeier, B. J., \& Bostrom, A. (1996). The relationship between perceived coaching behaviors and team cohesion among baseball and softball players. Sport Psychologist, 10(4), 367-381.

[18] Goddard, R. D., Hoy, W. K., \& Woolfolk Hoy, A. (2000). Collective teacher efficacy: Its meaning, measure, and effect on student achievement. American Education Research Journal, 37(2), 479-507.

[19] Goddard, R. D., \& Goddard, Y. L. (2001). A multilevel analysis of the relationship between teacher and collective efficacy in urban schools. Teaching and Teacher Education, 17, 807-818.

[20] Göker, Süleyman D. (2005). A School-based management and supervision model (SBMS) in EFL Schools. The Internet TESL Journal, January 2005.

[21] Göker, Süleyman D. (2006a). Leading for learning: Reflective management in EFL. Theory into Practice. Spring 2006, Volume. 45, No. 2, pp. 187-196.

[22] Göker, Süleyman D. (2006b). Impact of peer coaching on self-efficacy and instructional skills in TEFL teacher education. System, An International Journal of Educational Technology and Applied Linguistics. 2006. 34/2 pp. 239-254.

[23] Greenglass, E. R., \& Burke, R. J. (2003). Teacher stress. In M. F. Dollard, A. H. Winefield, \& H. R. Winefield (Eds.), Occupational stress in the service professions (pp. 213-236). New York: Taylor \& Francis.

[24] Hochwarter, W. A., Kiewitz, C., Castro, S. L., Perrewe, P. L., \& Ferris, G. R. (2003). Positive affectivity and collective efficacy as moderators of the relationship between perceived politics and job satisfaction. Journal of Applied Social Psychology, 33, 1009-1035.

[25] Hoy, W. K., Sweetland, S. R., \& Smith, P. A. (2002). Toward an organizational model of achievement in high schools: The significance of collective efficacy. Educational Administration Quarterly, 38(1), 77-93.

[26] Jepson, E., \& Forrest, S. (2006). Individual contributory factors in teacher stress: The role of achievement striving and occupational commitment. British Journal of Educational Psychology, 76, 183-197.

[27] Jex, S. M., \& Bliese, P. D. (1999). Efficacy beliefs as a moderator of the impact of work-related stressors: A multilevel study. Journal of Applied Psychology, 84, 349-361.

[28] Jex, S. M., \& Thomas, J. L. (2003). Relations between stressors and group perceptions: Main and mediating effects. Work and Stress, 17, 158-170.

[29] Judge, T. A., Thoresen, C. J., Bono, J. E., \& Patton, G. K. (2001). The job satisfaction-job performance relationship: A qualitative and quantitative review. Psychological Bulletin, 127, 376-407.

[30] Klassen, R. M., Chong, W. H., Huan, V. S., Wong, I., Kates, A., \& Hannok, W. (2008). Motivation beliefs of secondary school teachers in Canada and Singapore: A mixed methods study. Teaching and Teacher Education, 24, 1919-1934.

[31] Klassen, R. M., Usher, E. L., \& Bong, M. (2010). Teachers' Collective Efficacy, Job Satisfaction, and Job Stress in CrossCultural Context. The Journal of Experimental Education, 78, 464-486. 
[32] Kokkinos, C. M. (2007). Job stressors, personality and burnout in primary school teachers. British Journal of Educational Psychology, 77, 229-243.

[33] Kyriacou, C. (2001). Teacher stress: directions for future research. Educational Review, 53, $27-35$.

[34] Locke, E. A. (1976). The nature and causes of job satisfaction. In M. D. Dunnette (Ed.), Handbook of Industrial and Organizational Psychology (pp. 1297-1349). Chicago, IL: Rand McNally.

[35] Manthei, R., Gilmore, A., Tuck, B., \& Adair, V. (1996). Teacher stress in intermediate schools. Educational Research, 38, 319.

[36] Mayer, D. P., Mullens, J. E., \& Moore, M. T. (2000). Monitoring school quality:An indicators report. Washington, DC: U.S. Department of Education, Office of Educational Research and Improvement: National Center for Education Statistics. Available as a pdf from http://www.nces.ed .gov/pubsearch/pubsinfo.asp?pubid=2001030. Retrieved on March 12, 2012.

[37] Nagy, M. S. (2002). Using a single-item approach to measure facet job satisfaction. Journal of Occupational and Organizational Psychology, 75, 77-86.

[38] National Education Association. (2007). Education statistics: Rankings and estimates 2006. Retrieved January 2, 2012, from http://www.nea.org/edstats/index.html

[39] Pajares, F. (1994). Role of self-efficacy and self-concept beliefs in mathematical problem solving: A path analysis. Journal of Educational Pyschology, 86, 193-203.

[40] Pajares, F. (1997). Current directions in selfefficacy research. In M. L. Maehr \& P. R. Pintrich (Eds.), Advances in motivation and achievement (pp. 1-49). Greenwich, CT: JAI Press.

[41] Raudenbush, S. W., Rowan, B., \& Cheong, Y. F. (1992). Contextual effects on the self-perceived efficacy of high school teachers. Sociology of Education, 65, 150-167.

[42] Ross, J. A., \& Gray, P. (2006). Transformational leadership and teacher commitment to organizational values: The mediating effects of collective teacher efficacy. School Effectiveness and School Improvement, 17, 179-199.

[43] Sampson, R. J., Morenoff, J. D., \& Earls, F. (2000). Beyond social capital: Spatial dynamics of collective efficacy for child ren. American Sociological Review, 64, 633-660.

[44] Skaalvik, E. M., \& Skaalvik, S. (2007). Dimensions of teacher self-efficacy and relations with strain factors, perceived collective teacher efficacy, and teacher burnout. Journal of Educational Psychology, 99, 611-625.

[45] Tschannen-Moran, M., Woolfolk Hoy, A. W., \& Hoy, W. K. (1998). Teacher efficacy: Its meaning and measure. Review of Educational Research,68, 202-248.

[46] Tschannen-Moran, M., \& Barr, M. (2004). Fostering student learning: The relationship of collective teacher efficacy and student achievement. Leadership and Policy in Schools, 3, 187-207.

[47] Ware, H., \& Kitsantas, A. (2007). Teacher and collective efficacy beliefs as predictors of professional commitment. The Journal of Educational Research, 100, 303-310.

[48] Woolfolk Hoy A., \& Davis, H. A. (2006). Teacher self-efficacy and its influence on the achievement of adolescents. In F. Pajares \& T. Urdan (Eds.), Adolescence and education, Vol. 5: Self-efficacy and adolescence (pp. 117-137). Greenwich, CT: Information

[49] Yoon, J. S. (2002). Teacher characteristics as predictors of teacher-student relationships: Stress, negative affect, and selfefficacy. Social Behavior and Personality, 30, 485-494. Age Publishing.

Suleyman Davut Göker, EdD, is an associate professor of Educational Administration and Supervision and the chair of Department of English Translation and Interpretation, Faculty of Humanities at the Girne American University, North Cyprus. His research focuses on reflective management and supervision and curriculum development in EFL schools. He received his EdD in Educational Administration and Supervision from Dokuz Eylul University, Turkey.

Assoc. Prof. Dr. Suleyman Davut Goker began his career as a director at Diltek English School in Istanbul. He worked as an EFL lecturer at the School of Foreign Languages, Dokuz Eylul University and completed his M.A and Ph.D. in Izmir. He worked as a part-time legal interpreter at the Criminal Courts, Izmir and English examiner of the European Law Students' Association (ELSA) and ISIAC. During his Ph.D study, he has been to Glasgow University as a visiting scholar. He developed an instructional supervision model in ELT for the Ministry of National Education, Turkey. In 1999, he was appointed as an assistant professor of ELT and and director to English Preparatory School, European University of Lefke. He acted as the head and M.A. TEFL coordinator of ELT Department, EUL between 2000 and 2004. In 2002, he went to Bahrain and Jordan as a university representative for a prospective affiliation agreement and the International Education fair. In May 2004, he has been to College of Education, The Ohio State University as a visiting scholar for 5 months and he completed a postdoc research study entitled "The Impact of Peer Coaching on EFL Teachers' Self-efficacy and Instructional Skills". He worked as assistant professor of ELT to the Faculty of Education, Eastern Mediterranean University between September 2004 and September 2006. He was appointed as Associate Professor in July 2008. As of 15 September 2006, he has been acting as head of Department of Translation and Interpreting at GAU. 